\title{
Espécies forrageiras para produção de leite em solos de várzea ${ }^{1}$
}

\author{
Domingos Sávio Queiroz ${ }^{2}$, Daniel Rume Casagrande ${ }^{3}$, Guilherme de Souza Moura ${ }^{4}$, \\ Edilane Aparecida da Silva ${ }^{5}$, Maria Celuta Machado Viana ${ }^{6}$, José Reinaldo Mendes Ruas ${ }^{7}$
}

1 Financiado pela FAPEMIG

2 EPAMIG. Membro do INCT Ciência Animal.

${ }^{3}$ Estudante de Zootecnia da UFV. Bolsista BIC FAPEMIG.

4 Zootecnista. Bolsista de Aperfeiçoamento FAPEMIG

${ }^{5}$ EPAMIG. Bolsista de Produtividade da FAPEMIG e membro do INCT Ciência Animal.

${ }^{6}$ EPAMIG. Bolsista de Produtividade da FAPEMIG.

${ }^{7}$ EPAMIG. Bolsista de Produtividade do CNPq e membro do INCT Ciência Animal.

RESUMO - Objetivou-se com este trabalho avaliar a disponibilidade de forragem, a composição morfológica e química do pasto, a capacidade de suporte do pasto e a produção de leite de vacas em três gramíneas forrageiras sob lotação contínua e taxa variável em solo de várzea. O delineamento experimental foi inteiramente casualizado com três tratamentos e três repetições. Os tratamentos constituíram-se das gramíneas Paspalum atratum cv. Pojuca, Brachiaria humidicola cv. Llanero e capim-tangola, híbrido natural de Brachiaria arrecta e Brachiaria mutica. A taxa de lotação foi ajustada para manter a forragem disponível entre 2.000 e $3.000 \mathrm{~kg}$ de massa seca por hectare. O período avaliado foi de novembro de 2003 a maio 2004. Não houve diferença significativa entre as espécies quanto à disponibilidade de massa seca de forragem verde, com valor médio de 2.902 kg/ha. O capim-pojuca apresentou 62\% de lâminas foliares e 38\% de colmo + bainha na massa seca de forragem verde, seguido pelo capim-humidícola com 49 e 51\% e o capim-tangola com 18 e 82\%, respectivamente. O capim-tangola apresentou teor mais alto de proteína bruta na lâmina foliar (15,41\%) que os capins humidícola (9,98\%) e pojuca (8,74\%) e menores de fibra (FDN e FDA). A produção individual das vacas refletiu o melhor valor alimentício do capim-tangola, cuja média diária $(10,27 \mathrm{~kg} / \mathrm{vaca})$ foi maior que no capim-pojuca $(7,80 \mathrm{~kg} / \mathrm{vaca})$ e semelhante ao obtido com capim-humidícola (9,16 kg/vaca). A produção de leite por área não foi afetada pela gramínea forrageira, com média de $27,8 \mathrm{~kg} / \mathrm{ha} \times \mathrm{dia}{ }^{-1}$, uma vez que a taxa de lotação um pouco mais alta no capim-pojuca, apesar de não apresentar diferença significativa, compensou a menor produção individual das vacas.

Palavras-chave: Brachiaria humidicola, capim-llanero, capim-pojuca, capim-tangola, Paspalum atratum

\section{Forage species for milk production in lowland soil}

ABSTRACT - The objective of this study was to evaluate the forage availability, pasture morphological and chemical composition, pasture carrying capacity and the milk production of cows on three forage grasses under continues stocking and the variable rate on lowland soil. The experimental design was completely randomized with three treatments and three replicates. The treatments were the Paspalum atratum cv Pojuca grass, Brachiaria humidicola cv Llanero grass and tangola grass (natural hybrid of Brachiaria arrecta and Brachiaria mutica). The stocking rate was adjusted to maintain the forage available between 2.000 and $3.000 \mathrm{~kg}$ dry matter per hectare. The period evaluated was from November 2003 to May 2004. There was no significant difference between the species when the dry matter availability of green forage was evaluated, with mean value of $2.902 \mathrm{~kg} / \mathrm{ha}$. The pojuca grass had $62 \%$ of leaf blade and $38 \%$ of stem + sheath in green forage dry mass, followed by humidícola grass with 49 and 51\% and tangola grass with 18 and 22\%, respectively. The tangola grass showed higher level of crude protein on the leaf blade (15.41\%) than humidícola $(9.98 \%)$ and pojuca (8.74\%) grasses and lower levels of fiber (NDF and ADF). The individual production of cows was affected by the better nutritional value of the tangola grass. The average daily production of this grass was higher $(10.27 \mathrm{~kg} / \mathrm{cow})$ than the pojuca grass $(7.8 \mathrm{~kg} / \mathrm{cow})$ and had similar value to humidícola grass $(9.16 \mathrm{~kg} / \mathrm{cow})$. The milk production per area, with had mean of $27.8 \mathrm{~kg} / \mathrm{ha} \times$ day $^{-1}$, was not affected by the forage grasses because the more high stocking rate of pojuca grass, although not significant, compensated the lower individual production.

Key Words: Brachiaria humidicola, llanerograss, Paspalum atratum, pojucagrass, tangolagrass 


\section{Introdução}

No Brasil a área de várzea pode chegar a 35 milhões de hectares (Fageria et al., 2007). Em Minas Gerais há aproximadamente 1,4 milhão de hectares de várzeas passíveis de utilização na agricultura. A quase totalidade dessas áreas encontra-se com pastos formados naturalmente, com baixo potencial de produção, alta infestação com plantas daninhas, com ocorrência de espécies tóxicas, epinescentes e de baixa palatabilidade, provocando redução na capacidade de suporte desses pastos e na produtividade animal (Tuffi Santos et al., 2004). A utilização racional dessas áreas pode contribuir estrategicamente para a redução do custo de produção de leite pela sua capacidade de permitir o alongamento da estação de pastejo durante o período seco do ano, prolongando a estação de pastejo ao final das chuvas e antecipando ao inicio das águas. O estudo de espécies forrageiras que reúnam as qualidades de resistência ao ambiente de alagamento e capacidade de rebrota a pastejo frequente pode contribuir para a maior utilização de imensas áreas de várzeas hoje pouco aproveitadas. Existem diversas espécies forrageiras pouco exigentes em arejamento e que têm sido usadas na formação de pastagens em várzeas, como exemplo o capim-angola, capim-tangola, capim-estrela africana, capim-coast cross e capim-setária. Novas espécies e cultivares adaptados a essa condição têm sido lançados.

Existem poucos estudos com as espécies tolerantes ao alagamento, particularmente em campo, ainda mais com avaliação da produção animal. Alvim et al. (1992) avaliaram a produção de leite em capim-angola (Brachiaria mutica) sob diferentes disponibilidades de forragem, adubadas ou não com 125 kg de nitrogênio por hectare. Produções ao redor de 8 a $9 \mathrm{~kg}$ de leite por vaca/dia, correspondendo a 15 a $20 \mathrm{~kg}$ de leite por hectare/dia foram obtidas com taxas de lotação entre 1,5 e 2,2 vacas por hectare. Maior número de estudos é encontrado sob condições de várzea na região Sul, utilizando espécies temperadas, particularmente azevém (Marchezan et al., 2002; Rosito et al., 2004; Difante et al., 2005 e 2006 ). Nessas condições, desempenhos muito altos dos animais são observados, com ganhos diários de $1 \mathrm{~kg}$ e capacidade de suporte em torno de 2,5 unidades animais por hectare. Objetivou-se com este trabalho avaliar a produção e o valor alimentício de três gramíneas forrageiras submetidas ao pastejo com lotação contínua e taxa variável e a produção de leite por vacas lactantes em solo de várzea.

\section{Material e Métodos}

O experimento foi conduzido na Fazenda Experimental de Leopoldina, da EPAMIG, localizada a $21^{\circ} 28^{\prime}$ de latitude sul, $42^{\circ} 43^{\prime}$ de longitude e $184 \mathrm{~m}$ de altitude, durante o período de setembro de 2003 a maio de 2004. A região possui clima tropical úmido (megatérmico) de savana, com inverno seco e verão chuvoso (Figura 1), cuja temperatura do mês mais frio é superior a $18{ }^{\circ} \mathrm{C}$ (Antunes, 1986).

A área experimental foi composta de 7,5 hectares, dividida igualmente em nove unidades experimentais (piquetes) de 0,83 ha. O experimento foi implantado num solo de várzea sujeito a inundação periódica, com as seguintes características químicas na camada de 0 a $20 \mathrm{~cm}$ : pH em $\mathrm{H}_{2} \mathrm{O}$; 5,9; fósforo e potássio (Melich-1) 2 e $38 \mathrm{mg} / \mathrm{dm}^{3}$, respectivamente; cálcio, magnésio e alumínio ( $\mathrm{KCl} 1 \mathrm{~mol} / \mathrm{L}$ ), 1,$0 ; 0,5$ e $0,2 \mathrm{cmol}_{\mathrm{c}} / \mathrm{dm}^{3}$, respectivamente; matéria orgânica, 2,04 dag/kg, saturação por bases, 33\% e CTC pH $7,4,9 \mathrm{cmol}_{\mathrm{c}} / \mathrm{dm}^{3}$.

Os tratamentos constituíram de três gramíneas forrageiras: Paspalum atratum cv. Pojuca (capim-pojuca); Brachiaria humidicola cv. Llanero (capim-humidícola) e um híbrido natural entre o capim-tannergrass (Brachiaria arrecta (Dur \& Schinz) Stent) e o capim-angola (Brachiaria mutica (Forssk.) Stapf), denominado capim-tangola.

Em julho de 2002, antes da formação dos pastos, realizou-se a limpeza da área, que se encontrava totalmente tomada por invasoras, como capim-capituba, espécie do gênero Paspalum, altamente invasiva em áreas de várzea e limoeiro cravo (Citrus limonia (L.) Osbeck). Para o arranquio e remoção das plantas de limoeiro cravo foi necessário o uso de trator de esteira. O terreno foi gradeado duas vezes, com grade pesada, ocasião em que foi feita a calagem para elevar a saturação por bases do solo a 50\%. Posteriormente, realizaram-se mais duas operações de gradagem, com grade leve, para nivelar o terreno.

A formação dos pastos iniciou-se em novembro de 2002, em que a semeadura do capim-pojuca e do capim-

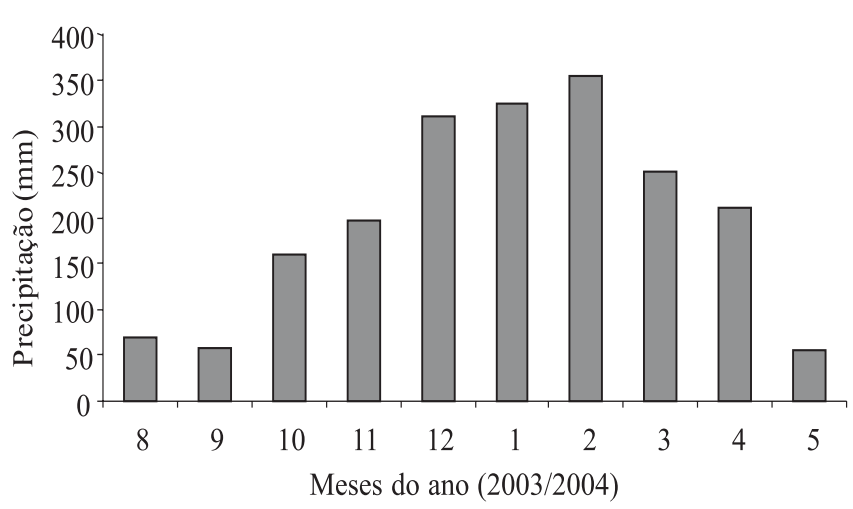

Fonte: Cooperativa dos Produtores de Leite de Leopoldina, MG.

Figura 1 - Precipitação pluviométrica durante o período de avaliação do experimento. 
humidícola foi realizada com o auxilio de uma semeadora/ adubadora própria para gramíneas forrageiras. Foram utilizados $15 \mathrm{~kg}$ de semente de cada espécie forrageira e $300 \mathrm{~kg}$ de superfosfato simples por piquete, o equivalente a $65 \mathrm{~kg} /$ ha de $\mathrm{P}_{2} \mathrm{O}_{5}$. O valor cultural das sementes foi de $20 \%$ e de $35 \%$, equivalendo a 3,6 e $6,3 \mathrm{~kg} / \mathrm{h}$ de sementes puras viáveis (SPV) para o capim-pojuca e o capim-humidícola, respectivamente. O capim-tangola foi plantado por meio de mudas obtidas na própria fazenda da EPAMIG. A adubação com superfosfato simples correspondente a $65 \mathrm{~kg} / \mathrm{ha}$ de $\mathrm{P}_{2} \mathrm{O}_{5}$ foi realizada a lanço, antes do plantio das mudas.

Durante os meses de dezembro de 2002 e janeiro de 2003, a precipitação foi de $835 \mathrm{~mm}$, com chuvas quase diárias. Essa grande quantidade de chuvas no período de implantação proporcionou que espécies nativas da área, conhecidas popularmente com cabelo de sapo, tiriricão e capim-macarrão tivessem alta incidência no pasto, favorecidas pelo excesso de umidade no solo. Em função disso, o manejo do pastejo durante esse período foi conduzido com lotação abaixo do potencial para favorecer o estabelecimento das gramíneas em estudo. Em março de 2003, foram realizadas aplicações de herbicida à base de 2,4 D, nos piquetes formados com capim-humidícola e capim-tangola devido à alta infestação de plantas invasoras de folha larga, principalmente do gênero Sida.

No início do período chuvoso do ano agrícola de 2003/ 2004, a fim de consolidar a formação dos pastos e reduzir a quantidade de invasoras realizou-se um corte de uniformização nas áreas com maiores infestações de plantas invasoras. Em seguida, realizou-se a primeira parcela da adubação de manutenção, a qual foi dividida em três aplicações realizadas em dezembro de 2003, janeiro de 2004 e abril de 2004. Cada aplicação constituiu de $180 \mathrm{~kg} / \mathrm{ha}$ da fórmula 20-05-20, totalizando 108, 27 e $108 \mathrm{~kg} / \mathrm{ha}$ de $\mathrm{N}, \mathrm{P}_{2} \mathrm{O}_{5}$ e $\mathrm{K}_{2} \mathrm{O}$, respectivamente.

Para o pastejo foram utilizadas vacas mestiças holandês/ zebu, agrupadas por peso, período de lactação e produção de leite e distribuídas ao acaso nos tratamentos. O sistema de pastejo utilizado foi de lotação continua com taxa de lotação variável em função da massa de forragem. Para isto, foram utilizadas duas vacas-teste por piquete, com período de lactação de dois até cinco meses. Quando necessário foram adicionadas ou retiradas vacas lactantes (animais de equilíbrio) a fim de manter a massa de forragem verde entre 2.000 e $3.000 \mathrm{~kg} / \mathrm{ha}$. O período experimental iniciou-se em dezembro de 2003 e terminou quando não foi possível manter os dois animais-teste no piquete, o que aconteceu em maio de 2004. Nessa ocasião houve um ataque intenso de lagartas da espécie Pseudaletia sequax (lagarta do trigo) nos piquetes de capim-tangola, impedindo a continuidade na avaliação do experimento. Os capins pojuca e humidícola também foram atacados pela lagarta, mas os danos foram pequenos.

Em março de 2004 promoveu-se um rearranjo no experimento em decorrência de algumas vacas atingirem período de lactação superior ao estipulado no experimento. Novas vacas em estágios iniciais de lactação substituíram os animais com avançado período de lactação, mantendo-se os critérios de uniformidade dos grupos entre os tratamentos. Além do pasto, as vacas que produziam acima de $5 \mathrm{~kg}$ de leite, receberam diariamente ração concentrada na proporção de $1 \mathrm{~kg}$ para cada $3 \mathrm{~kg}$ de leite.

As vacas foram ordenhadas duas vezes ao dia e o controle leiteiro foi realizado semanalmente. A produção média de leite foi calculada pela média da produção dos dois animais-teste. A produção das vacas-teste, obtida a cada semana, gerou a média que foi multiplicada pelo número de vacas/ha $\times \mathrm{dia}^{-1}$ obtendo-se a produção de leite/ha $\times \mathrm{dia}^{-1}$. A taxa de lotação foi calculada em função do número de animais/ha e peso corporal, em unidade animal (UA $=450 \mathrm{~kg}$ ).

A massa de cada gramínea foi obtida mensalmente, por meio de seis amostragens em cada piquete, colhendo-se, em cada amostra, a forragem contida em $1 \mathrm{~m}^{2}$ de área, cortada a $5 \mathrm{~cm}$ do solo. Dentro dessa área, antes da colheita da forragem, foram tomadas três medidas da altura do dossel e foi estimada a cobertura vegetal por dois avaliadores. A forragem colhida de cada amostra foi pesada e retirada uma subamostra. Ao final da colheita e pesagem das seis amostras por piquete, as subamostras foram agrupadas para formar uma amostra composta e separada em: gramínea principal (gramínea em estudo), outras forrageiras (outras espécies de valor forrageiro), invasoras (espécies sem valor forrageiro) e material morto. A gramínea principal foi separada em lâmina foliar e colmo+bainha. As amostras foram levadas à estufa a temperatura de $65{ }^{\circ} \mathrm{C}$ por 72 horas para présecagem. O peso seco foi usado para a determinação da composição botânica do pasto. As amostras de lâmina foliar, colmo+bainha e outras forrageiras foram submetidas à análise no Laboratório de Nutrição Animal do DZO/UFV, quanto aos teores de proteína bruta (PB), fibra em detergente neutro (FDN), fibra em detergente ácido (FDA) conforme procedimentos descritos por Silva \& Queiroz (2002). As amostras de capim-tangola foram analisadas quanto ao teor

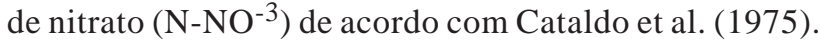

Os dados foram analisados seguindo um delineamento inteiramente casualizado, em parcelas subdivididas, com três repetições (piquetes), em que foram avaliadas as gramíneas nas parcelas e o tempo nas subparcelas. Para isto 
agruparam-se os dados em dois períodos: águas (verão) e transição águas/secas (outono). Utilizou-se o programa PROC GLM do pacote estatístico SAS (Statistical Analysis System, versão 9.2) e as médias comparadas pelo teste Tukey a $10 \%$ de probabilidade.

\section{Resultados e Discussão}

Não houve diferença na altura média do dossel entre as espécies $(\mathrm{P}>0,10)$, porém a mesma reduziu com o avanço do período experimental $(\mathrm{P}<0,10)$. A biomassa total não variou $(\mathrm{P}>0,10)$ com a espécie de gramínea em estudo (Tabela 1 ). No entanto, observou-se maior proporção de invasoras $(\mathrm{P}<0,10)$ nos pastos formados com capim-humidícola em relação aos pastos formados com capim-pojuca. No capimtangola a proporção de invasoras não diferiu de nenhum dos dois (Tabela 1). Em valores absolutos, a biomassa de invasoras nos pastos com capim-humidícola também foi maior em relação aos pastos com capins tangola e pojuca. Nos pastos de capim-pojuca obteve-se maior valor de material morto em relação às demais gramíneas, seja em valores absolutos ou relativos. Em valores absolutos, os pastos de capim-humidícola foram os que apresentaram menor massa de material morto. Dessa forma, as massas de forragem verde, as quais foram compostas pela massa de forragem das gramíneas principais e de outras plantas com valor forrageiro, foram similares entre os diferentes tratamentos $(\mathrm{P}>0,10)$, indicando que o critério de manejo adotado com a finalidade de padronizar a massa de forragem verde foi eficiente.

O comportamento de pastejo dos animais no capimpojuca justifica a maior proporção de material morto nessa espécie. Semelhantemente ao capim-jaraguá e em algumas cultivares de Panicum, o capim-pojuca torna-se pouco palatável depois de alcançar certa altura de crescimento. Sob lotação contínua é difícil controlar a uniformidade de pastejo pelo animal, que tende a fazer mosaicos no pasto, com áreas muito pastejadas e outras menos pastejadas, elevando as perdas por senescência, mesmo com ajustes constantes na taxa de lotação. Essa observação permite levantar a hipótese de que o capim-pojuca propiciará melhor rendimento se utilizado sob pastejo rotativo, método de pastejo que permite melhor controle da remoção de forragem.

Com relação aos efeitos dos períodos, constatou-se redução na biomassa total, assim como da massa de invasoras e da massa de forragem verde, com o avançar do período das águas para a transição águas/secas ( $\mathrm{P}<0,10)$ (Tabela 1). Não houve efeito dos períodos estudados sobre a quantidade de material morto $(\mathrm{P}>0,10)$, no entanto, a porcentagem de material morto foi maior no período de transição, enquanto que a proporção massa de forragem verde reduziu nesse período e a de invasoras não se alterou. No período de transição águas/seca, houve redução na massa de forragem verde e de seus componentes, folha e colmo, no entanto, a redução da massa de folhas foi mais acentuada que a massa de colmos, acarretando em queda na relação lâmina foliar/ colmo+bainha. Este fenômeno ocorre porque, nesse período, as condições ambientais como precipitação, luminosidade e temperatura não são tão favoráveis ao crescimento de gramíneas forrageiras quanto no período da águas (verão). Cunha et al. (2001) observaram redução do alongamento de folha e do perfilhamento de capim-pojuca com avançar do período experimental do período de águas para transição águas/seca. Fatos que podem justificar a variação da massa de forragem e da estrutura do dossel ao longo do período experimental, aliado às variações dos demais fatores ambientais, os quais determinam as variações morfogênicas de gramíneas forrageiras.

Ao separar a fração de massa de forragem verde, nos seus componentes, massa forragem da gramínea principal e de outras plantas com potencial forrageiro, verificou-se que os pastos com capim-pojuca foram os que apresentaram maior proporção da gramínea principal em relação às outras forrageiras. Nesse caso, 93,8\% da massa de forragem verde foi da gramínea principal, enquanto que nos pastos de capim-humidícola, apenas $48,4 \%$ foi da gramínea principal

Tabela 1 - Características morfológicas, estruturais e de produção dos pastos de acordo com a gramínea e o período de avaliação

\begin{tabular}{|c|c|c|c|c|c|c|}
\hline \multirow[t]{2}{*}{ Variável } & \multicolumn{3}{|c|}{ Gramínea forrageira } & \multicolumn{2}{|c|}{ Período } & \multirow[t]{2}{*}{$\mathrm{CV}, \%$} \\
\hline & Pojuca & Humidícola & Tangola & Águas & Transição & \\
\hline Altura (cm) & $29,9 a$ & $31,9 a$ & $33,5 a$ & $32,3 \mathrm{~A}$ & $26,3 \mathrm{~B}$ & 11,6 \\
\hline Material morto (t/ha) & $1,43 a$ & $0,60 \mathrm{c}$ & $0,81 b$ & $0,91 \mathrm{~A}$ & $0,98 \mathrm{~A}$ & 18,8 \\
\hline Massa de invasoras (t/ha) & $0,21 b$ & $0,63 \mathrm{a}$ & $0,38 b$ & $0,53 \mathrm{~A}$ & $0,29 B$ & 31,2 \\
\hline MVS (t/ha) & $2,65 a$ & $2,78 \mathrm{a}$ & $3,01 \mathrm{a}$ & $3,25 \mathrm{~A}$ & $2,37 \mathrm{~B}$ & 17,8 \\
\hline Massa de colmos (t/ha) & $0,94 b$ & $0,73 b$ & $1,79 \mathrm{a}$ & $1,28 \mathrm{~A}$ & $1,03 \mathrm{~B}$ & 19,2 \\
\hline Relação lâmina foliar/colmo+bainha & $1,64 \mathrm{a}$ & $0,95 b$ & $0,21 \mathrm{c}$ & $1,02 \mathrm{~A}$ & $0,85 \mathrm{~B}$ & 10,2 \\
\hline
\end{tabular}


(Tabela 2). Dessa forma, nos pastos de capim-pojuca a massa de forragem da gramínea principal foi superior a dos pastos com capim-humidícola, enquanto o capim-tangola não apresentou diferença dos dois.

Ao comparar as três gramíneas em estudo com relação à massa de forragem e estrutura do pasto, o capim-pojuca se destacou, principalmente com relação à massa de lâmina foliar, que em comparação as outras duas espécies, apresentou maior proporção dessa fração (61,9\% da massa de forragem verde). Observou-se que o capim-pojuca apresentou elevação muito tardia do meristema apical, reduzindo drasticamente a massa de colmo, sendo que a maior parte da fração classificada como colmo+bainha, tratava-se de pseudocolmo. Ao contrário, o capim-tangola apresentou elevação precoce do meristema apical e participação de lâminas foliares na matéria seca muito baixa, de apenas $16,8 \%$ da forragem produzida, com grande acúmulo de colmo na fração inferior do dossel forrageiro, gerando uma relação lâmina/colmo+bainha de apenas 0,21. A fração colmo+bainha é pouco preferida pelos animais em pastejo e pode servir de impedimento físico para bocados profundos dos animais, reduzindo o tamanho desse e, consequentemente, o consumo de forragem. Durante as avaliações percebeu-se claramente um gradiente no dossel do capim-tangola, formado por uma camada de colmos abaixo da camada de folhas, correspondendo a aproximadamente metade do dossel, ou seja, $15 \mathrm{~cm}$. Especula-se que o manejo do pastejo poderia ter sido conduzido para redução dessa camada de colmos para em torno de $5 \mathrm{~cm}$, mantendo-se a camada de folhas em $15 \mathrm{~cm}$, obtendo-se dosséis com em torno de $20 \mathrm{~cm}$ de altura e melhorando a relação folha/colmo e a estrutura do pasto para otimizar o consumo. As implicações dessa estratégia de manejo do capim-tangola a $20 \mathrm{~cm}$ de altura, sob pastejo com lotação contínua, são difíceis de serem previstas, mas podem servir de referência ao manejador do capim-tangola em relação a condição observada nesse experimento. Em capim-marandu, Andrade (2003) verificou aumento de quase cinco vezes no ganho diário de novilhos com o aumento nas alturas de pastejo de 10, 20, 30 e 40 cm, sob lotação contínua com taxa de lotação variável. O autor atribuiu a melhora no desempenho ao aumento de consumo de forragem, uma vez que as diferenças de valor nutritivo foram pequenas. Entretanto, Carnevalli et al (2001) não encontraram diferença no desempenho individual e por área de carneiros em capimtifton 85 pastejado as alturas de 5, 10, 15 e $20 \mathrm{~cm}$, sob pastejo contínuo e taxa de lotação variável.

O capim-pojuca foi a gramínea que teve menor proporção de colmo+bainha, enquanto a proporção dessa fração foi intermediária no capim-humidícola. Embora a proporção de colmo+bainha tenha sido menor no capimpojuca em relação ao capim-humidícola, a massa dessa fração não diferiu entre estas duas gramíneas, isto porque a massa de forragem do capim-humidícola foi baixa. Em ambas gramíneas a massa de colmo+bainha foi inferior ao do capim-tangola. Resultado inverso foi obtido com a massa de lâmina foliar, em que, observou-se massa superior no capim-pojuca em relação as demais gramíneas. Dessa forma, a relação lâmina foliar:colmo+bainha foi superior no capim-pojuca, seguido pelo capim-humidícola e por fim o capim-tangola. Essas variações podem ser atribuídas às características contrastantes de crescimento das espécies estudadas. O capim-pojuca apresenta crescimento cespitoso, favorecendo a relação folha/colmo, enquanto os capins tangola e humidícola apresentam crescimento decumbente, promovendo maior acúmulo de colmo. Com características de crescimento semelhantes aos dois últimos, a $B$. decumbens apresentou de 62 a 64\% de colmo na primavera/verão (Fagundes et al., 2005), enquanto cultivares do gênero Cynodon apresentaram de 60 a $75 \%$ de colmo na massa de forragem durante a estação de crescimento (Pinto et al., 2000).

Apesar das diferenças nessas variáveis, os capins foram manejados à mesma altura, o que levou a construção de estruturas de dossel bem contrastantes. Poder-se-ia especular que houve prejuízo no manejo dos capins tangola e humidícola, que exigiriam redução mais intensa de sua altura de pastejo, para reduzir a proporção de colmos, particularmente no capim-tangola. Entretanto, estudos

Tabela 2 - Valores relativos das características morfológicas, estruturais e de produção de acordo com as gramíneas e o período de avaliação

\begin{tabular}{|c|c|c|c|c|c|c|}
\hline \multirow[t]{2}{*}{ Variável } & \multicolumn{3}{|c|}{ Gramínea forrageira } & \multicolumn{2}{|c|}{ Período } & \multirow[t]{2}{*}{$\mathrm{CV}, \%$} \\
\hline & Pojuca & Humidícola & Tangola & Águas & Transição & \\
\hline$\%$ invasoras & $5,0 \mathrm{~b}$ & $15,0 \mathrm{a}$ & $8,9 \mathrm{ab}$ & $11,4 \mathrm{~A}$ & $8,1 \mathrm{~A}$ & 50,3 \\
\hline$\%$ material morto & $33,8 \mathrm{a}$ & $15,8 b$ & $19,8 b$ & $19,6 \mathrm{~B}$ & $26,6 \mathrm{~A}$ & 25,0 \\
\hline$\%$ material verde & $61,2 b$ & $69,2 \mathrm{a}$ & $71,3 a$ & $69,0 \mathrm{~A}$ & $65,3 \mathrm{~B}$ & 6,4 \\
\hline$\%$ outras forrageiras & $6,2 b$ & $51,6 a$ & $27,5 a b$ & $27,1 \mathrm{~A}$ & $29,8 \mathrm{~A}$ & 20,6 \\
\hline$\%$ forrageira principal & 93,8 a & $48,4 b$ & $72,5 a b$ & $72,9 \mathrm{~A}$ & $70,2 \mathrm{~A}$ & 7,3 \\
\hline \% lâminas foliares & $61,9 a$ & $48,7 b$ & $16,8 \mathrm{c}$ & $44,8 \mathrm{~A}$ & $40,2 \mathrm{~B}$ & 6,1 \\
\hline \% colmos & $38,1 \mathrm{c}$ & $51,3 \mathrm{~b}$ & $83,2 \mathrm{a}$ & $55,2 \mathrm{~B}$ & $59,8 \mathrm{~A}$ & 4,5 \\
\hline
\end{tabular}

Médias seguidas de mesma letra na linha, minúsculas (efeito da gramínea) e maiúsculas (efeito do período), não diferem pelo teste Tukey a $10 \%$ de probabilidade. 
recentes com manejo de espécies decumbentes sob lotação continua mostraram ampla faixa de alturas de manejo em que a produção líquida se mantém estável (Nascimento Júnior et al., 2010). Para Cynodon spp. uma amplitude de condições de pasto variando entre 10 e $20 \mathrm{~cm}$ de altura de dossel apresenta taxas de acúmulo de forragem relativamente constantes e de valores altos (Pinto et al., 2001). Para capimmarandu esses valores ficaram entre 20 e $40 \mathrm{~cm}$ de altura (Sbrissia, 2004). Embora não haja estudos desse tipo com os capins tangola e humidícola, especula-se que a altura média obtida nesse estudo não esteja muito fora da faixa recomendada. Nesses estudos, a relação entre altura de pastejo e desempenho individual dos animais mostra resposta linear positiva até as alturas recomendadas (Andrade, 2003), o que é desejável na utilização dessas espécies para produção de leite.

A massa de forragem das outras plantas forrageiras variou em função da interação período experimental e espécies de forrageira $(\mathrm{P}<0,10)$. No período de águas a maior massa de forragem das outras forrageiras foi no pasto de capim-humidícola, seguido pelos de capim-tangola e capimpojuca (Tabela 3). Com avançar do período experimental, apenas nos pastos de capim-pojuca a massa de forragem de outras forrageiras não se alterou, nas demais, houve redução dessa variável na fase de transição águas/seca.

A maior massa de forragem da gramínea principal no pasto de capim-pojuca provavelmente foi ocasionada pela excelente germinação com bom estande, o que, aliado à rapidez de estabelecimento, reduziu a invasão de espécies indesejáveis ou de outras forrageiras nesses pastos. Já o capim-humidícola apresentou boa população de plantas nos piquetes, mas se estabeleceu lentamente, propiciando alta infestação de invasoras nativas da várzea e de outras espécies que colonizavam a área antes da implantação do pasto, como o capim-tangola. Apesar da baixa população de plantas de capim-tangola na área e da alta infestação de invasoras, decorrente do manejo inadequado antes da reforma do pasto, ele estava amplamente disseminado na área. Mesmo com o preparo do solo feito com diversas passagens de grade pesada e leve, mudas de capim-tangola sobreviveram no solo e rebrotaram após correção da acidez

Tabela 3 - Massa de forragem de outras forrageiras (t/ha) de acordo com a gramínea e o período de avaliação

\begin{tabular}{lcccc}
\hline Período & \multicolumn{3}{c}{ Gramínea forrageira } & Média \\
\cline { 2 - 4 } & Pojuca & Humidícola & Tangola & \\
\hline Águas & $0,07 \mathrm{cA}$ & $1,60 \mathrm{aA}$ & $1,04 \mathrm{bA}$ & 0,90 \\
Transição & $0,26 \mathrm{bA}$ & $1,11 \mathrm{aB}$ & $0,63 \mathrm{bB}$ & 0,46 \\
Média & 0,165 & 1,355 & 0,835 & \\
\hline
\end{tabular}

Médias seguidas de mesma letra, minúsculas na linha e maiúscula na coluna, não diferem pelo teste Tukey a $10 \%$ de probabilidade. e da adubação fosfatada do solo. Conforme descrito na metodologia, o controle com herbicida foi feito nos pastos de capim-humidícola e capim-tangola, no entanto, o capimtangola estabeleceu-se mais rapidamente, diminuindo a incidência de plantas invasoras e de outras forrageiras em relação ao capim-humidícola. Esses resultados corroboram a afirmação de Kalmbacher et al. (1997) de que a gramínea Paspalum atratum cv. Suerte teve rápido estabelecimento e alta persistência e competitividade, principalmente quando manejado com taxas de lotação inferior a 3,3 UA/ha. Por outro lado, a maior presença de invasoras no capimhumidícola, atribuída a sua lenta formação, corrobora o trabalho de Silva \& Dias-Filho (2001), em que o banco de sementes de invasoras em pastos de Brachiaria humidicola foi dez vezes maior que o de $B$. brizantha na região Amazônica, fato atribuído pelos autores à sua lenta formação.

A interação entre espécie forrageira e período experimental foi significativa $(\mathrm{P}<0,10)$ sobre a cobertura do solo pelas plantas forrageiras. O capim-pojuca foi a gramínea que apresentou menor cobertura do solo nos dois períodos experimentais (Tabela 4). Houve aumento da cobertura do solo nesses pastos com o avanço do período experimental. O capim-pojuca foi a única espécie testada com hábito de crescimento cespitoso, o que justifica a resposta obtida para cobertura do solo, pois esse tipo de crescimento é caracterizado pela formação de touceiras definidas e áreas sem a presença da planta forrageira. As três espécies apresentaram aumento da cobertura vegetal com o decorrer do experimento, o que mostra que a pressão de pastejo adotada não comprometeu o estande. No caso do capimpojuca, houve aumento significativo $(\mathrm{P}<0,10)$ da cobertura, de quase 15 pontos percentuais do verão para a transição chuva/seca. Provavelmente esse aumento é decorrente do manejo adotado. Sob pastejo contínuo o controle do pastejo é menos preciso e, particularmente no caso do capimpojuca, observou-se o pastejo em mosaico já mencionado. Na tentativa de controlar o pastejo, elevou-se a taxa de lotação, com redução na altura do dossel (Tabela 1). Concomitantemente outras alterações na estrutura do dossel ocorrem, como redução na relação tamanho/densidade de perfilhos (Sbrissia \& Da Silva, 2008). Cunha et al. (2001)

Tabela 4 - Cobertura do solo de acordo com a gramínea e o período de avaliação

\begin{tabular}{lcccc}
\hline Períodos & \multicolumn{3}{c}{ Gramínea forrageira } & \multirow{2}{*}{ Média } \\
\cline { 2 - 4 } & Pojuca & Humidícola & Tangola & \\
\hline Águas & $54,7 \mathrm{bB}$ & $76,4 \mathrm{aA}$ & $75,0 \mathrm{aA}$ & 68,7 \\
Transição & $69,1 \mathrm{bA}$ & $80,8 \mathrm{aA}$ & $79,6 \mathrm{aA}$ & 76,5 \\
Média & 61,9 & 78,6 & 77,3 & \\
\hline
\end{tabular}

Médias seguidas de mesma letra, minúsculas na linha e maiúscula na coluna, não diferem entre si pelo teste Tukey a $10 \%$ de probabilidade. 
observaram maior perfilhamento do capim-pojuca sob pastejo em relação a áreas não pastejadas. A plasticidade fenotípica faz com que a planta, mesmo as cespitosas, adote um crescimento mais horizontal, aumentando a cobertura do solo, com o aumento da pressão de pastejo e a redução na altura do dossel.

Os teores de proteína bruta da lâmina foliar do capimtangola foram superiores a 15\% da matéria seca (Tabela 5), enquanto nos capins pojuca e humidícola os valores observados foram de 9,0 e 9,7\%, respectivamente. Os teores de FDN e FDA foram menores na lâmina foliar do capimtangola, em relação às demais forrageiras, indicando superioridade do valor nutritivo dessa gramínea. É possível que a característica de crescimento do capim-tangola tenha propiciado o maior valor alimentício observado nessa espécie. Embora com disponibilidade de massa de forragem semelhante, o capim-tangola apresentou relação folha/colmo muito baixa, da ordem de apenas $20 \%$ da massa produzida. Especula-se que haja efeito de concentração do nitrogênio na massa foliar, gerando os altos teores de proteína bruta observados. Outra característica de crescimento do capimtangola, com folhas curtas, exige pouca estrutura de nervura para sustentar essa folha, propiciando os menores valores de fibra observados. Andrade et al. (2009) afirmam que o capim-tangola apresenta valor nutritivo acima da média das gramíneas tropicais e relatam teores médios de proteína bruta abaixo de $12 \%$ somente no mês de agosto, no estado do Acre, correspondente ao período seco. Alvim et al. (1992), estudando o capim-angola, progenitor do capimtangola, sob pastejo contínuo em várzea com adubação nitrogenada equivalente a aplicada nesse trabalho, obtiveram teores de proteína bruta em torno de 12,0\% na folha e de $13,3 \%$ na amostra de forragem selecionada com uso de animais fistulados, um pouco abaixo do valor obtido nesse trabalho, mas compatíveis com os valores obtidos para os capins pojuca e humidícola. O valor de $8,74 \%$ obtido no capim-pojuca pode ser considerado baixo, uma vez que apenas lâminas foliares verdes constituíam a amostra e que se promoveu adubação nitrogenada com 108 kg/ha na estação de crescimento em três aplicações. Esse valor é compatível com aqueles obtidos em amostras colhidas por pastejo simulado por Kalmbacher et al. (1997) em P. atratum cv. Suerte sob pastejo, cujo intervalo de variação foi de 7,4 a 14,2\%, dependendo da época de amostragem e da adubação nitrogenada aplicada.

O teor de proteína bruta da fração colmo + bainha não variou entre as gramíneas forrageiras, porém os teores de fibra em detergente neutro foram menores nas frações colmo+bainha do capim-pojuca em relação aos capins tangola e humidícola. No capim-pojuca a maior parte da fração colmo + bainha foi formada por pseudocolmo (bainha) em relação às demais gramíneas. Como a bainha é um tecido caracterizado por ter menor quantidade de tecido estrutural em relação ao colmo, justifica-se a resposta obtida para o teor de FDN. Da mesma forma, o teor de fibra em detergente ácido (FDA) foi menor na fração colmo+ bainha do capim-pojuca em relação ao capim-humidícola e similar ao da mesma fração do capim-tangola. Quanto à composição química, as outras forrageiras não apresentaram variação $(P>0,10)$ em função do pasto da gramínea principal em que estavam presentes, fato esperado, uma vez que as espécies que compunham essa fração foram as mesmas, independentemente da planta forrageira principal.

A composição química variou pouco em relação aos períodos experimentais. Apenas o teor de FDA da lâmina foliar e os teores de proteína do colmo+bainha e outra forrageiras reduziram com avanço do período das águas para a transição águas/secas. O teor de FDA da lâmina foliar

Tabela 5 - Composição química de folhas e de colmo da gramínea em estudo e de planta inteira de outras forrageiras

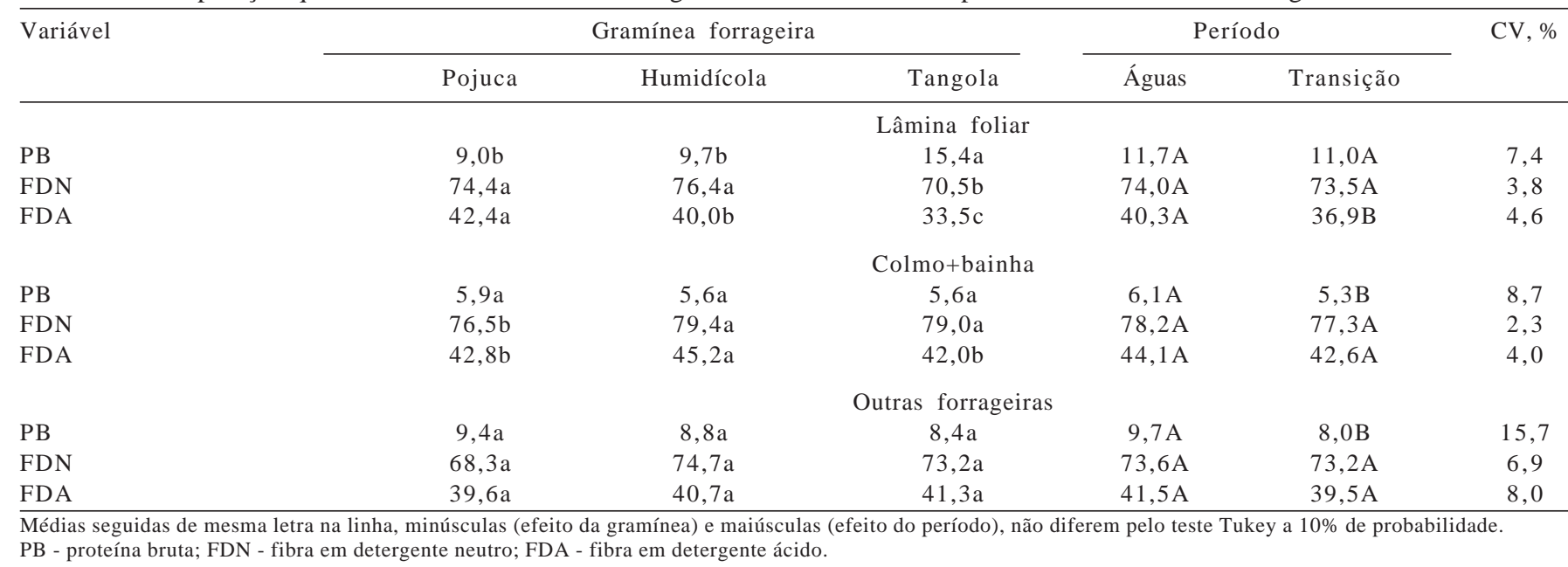


foi 8,5\% menor no período de transição em relação ao valor obtido durante o período das águas. Os teores de proteína bruta do colmo+bainha e das outras forrageiras foram, respectivamente, 13,1 e $17,5 \%$ menores no período de transição em relação ao período das águas.

Os altos teores de proteína bruta obtidos no capimtangola decorrem da alta concentração de nitrogênio na lâmina foliar, uma vez que não se analisa a proteína, mas o conteúdo de nitrogênio. Isso poderia levar a suspeita de elevados teores de $\mathrm{N}$ na forma de nitrato, uma vez que há registros na literatura de suspeitas de intoxicação provocados pelo capim-tannergrass, um dos progenitores do capimtangola (Tokarnia et al., 2002). A análise realizada somente nas amostras de capim-tangola obteve teores médios de nitrato entre 0,02 e 0,03 dag/kg de matéria seca, bem abaixo do limite de toxidez para bovinos. De acordo com Undersander et al. (2010), o limite de segurança para plantas forrageiras é de até $0,44 \mathrm{dag} / \mathrm{kg}$ de nitrato na matéria seca. Segundo esses autores, é muito difícil estabelecer a concentração exata de nitrato na planta que seja tóxica para os animais, pois a condição nutricional do animal aumenta ou diminui a gravidade da intoxicação.

A taxa de lotação foi maior nos pastos de capimhumidícola e capim-pojuca em relação ao capim-tangola $(\mathrm{P}<0,10)$. A taxa de lotação nos pastos de capim-tangola foi em média 82\% da observada nos demais pastos (Tabela 6). Essa resposta provavelmente está associada com a massa de forragem verde dos pastos. Embora a massa de forragem verde tenha sido semelhante, independentemente da espécie forrageira, a relação de forrageira principal e outras forrageiras e, principalmente, as relações folha/colmo variaram com as diferentes gramíneas em estudo. A massa de capim-tangola $83,2 \%$ foi de colmo+bainha, fração frequentemente recusada pelos animais em pastejo (Ruggieri et al., 2008). Dessa forma a massa de forragem que potencialmente poderia ser consumida foi menor nesses pastos e influenciou negativamente sobre a taxa de lotação. Em todos os pastos houve queda de $42,2 \%$ na taxa de lotação com avanço do período experimental. Esse resultado foi reflexo da massa de forragem que também reduziu com o avanço do período experimental. As condições climáticas provavelmente foram os fatores que determinaram a redução da massa de forragem e, consequentemente, da taxa de lotação.

A produção de leite diária por vaca foi maior nos pastos de capim-tangola em relação aos pastos de capim-pojuca. A produção de leite no capim-humidícola não diferiu de nenhum dos dois. Essa diferença parece estar mais relacionada com a composição química do que com a estrutura do pasto. Como não houve diferença na disponibilidade de massa seca e na altura do dossel (Tabela 1), a única característica estrutural avaliada que poderia explicar a diferença seria a relação folha/colmo, que foi muito baixa no capim-tangola. Nesse caso, se esperaria menor consumo e menor produção no capim-tangola, decorrente da alta presença de colmos no pasto, mas o resultado foi o contrário. Isso reforça a hipótese do melhor valor alimentício do capim-tangola, decorrente dos mais altos teores de proteína bruta e mais baixos valores de fibra (Tabela 5), que poderia favorecer a digestibilidade e, consequentemente, a taxa de passagem, propiciando maior consumo de forragem e maior produção de leite. De acordo com Sarmento (2003), o extrato explorado pelos bovinos em pastejo é próximo a 33\% da parte superior do dossel. Assim, a análise da estrutura do pasto obtida por avaliações ao nível do solo não permite inferir sobre o consumo de forragem pelos animais, mas somente em relação às características da planta forrageira. Entretanto, Euclides et al (2008) em três cultivares de Brachiaria brizantha concluíram que a estrutura do pasto é mais importante que o valor nutritivo na determinação do desempenho animal. A estrutura do pasto exerce grande influência no consumo de forragem de animais em pastejo, o que foi chamado por Poppi et al. (1987) como restrição não nutricional.

Mesmo com a menor produção de leite por vaca nos pastos de capim-pojuca a produção de leite por área foi similar, isso em função da maior taxa de lotação observada nesses pastos. O inverso ocorreu nos pastos de capimtangola que mesmo tendo a menor taxa de lotação, a produção por área foi similar aos demais em função da maior produtividade por animal. Nos pastos de capim-humidícola, tanto a produção de leite por vaca como a taxa de lotação

Tabela 6 - Taxa de lotação, produção de leite diária e produtividade de vacas leiteiras mestiças em pastejo de acordo com a gramínea e o período de avaliação

\begin{tabular}{|c|c|c|c|c|c|c|}
\hline \multirow[t]{2}{*}{ Variável } & \multicolumn{3}{|c|}{ Gramínea forrageira } & \multicolumn{2}{|c|}{ Período } & \multirow[t]{2}{*}{$\mathrm{CV}, \%$} \\
\hline & Pojuca & Humidícola & Tangola & Águas & Transição & \\
\hline Taxa de lotação (UA/ha) & $3,61 \mathrm{a}$ & $3,40 \mathrm{a}$ & $2,88 b$ & $4,17 \mathrm{~A}$ & $2,41 \mathrm{~B}$ & 16,7 \\
\hline Produção de leite (kg/dia) & $7,59 \mathrm{~b}$ & $9,17 \mathrm{ab}$ & $10,74 a$ & $9,66 \mathrm{~A}$ & $8,67 \mathrm{~B}$ & 11,5 \\
\hline Produtividade $\left(\mathrm{kg} / \mathrm{ha} \times \mathrm{dia}^{-1}\right)$ & $28,0 \mathrm{a}$ & $31,5 a$ & $30,0 \mathrm{a}$ & $37,7 \mathrm{~A}$ & $21,9 \mathrm{~B}$ & 10,3 \\
\hline
\end{tabular}

Médias seguidas de mesma letra na linha, minúsculas (efeito da gramínea) e maiúsculas (efeito do período), não diferem pelo teste Tukey a 10\% de probabilidade. 
tiveram valores intermediários obtendo produtividade por área igual as demais. Portanto, considerando somente a produção de leite por área, qualquer das gramíneas estudadas poderia ser utilizada em área de várzea para produção de leite. A escolha depende da disponibilidade de mudas e/ou sementes na região.

Dois aspectos do manejo do pastejo adotado neste experimento merecem consideração em futuros experimentos com essas espécies. A altura do dossel do capim-tangola sob lotação contínua, mantida em 33 cm de média, propiciou intenso acúmulo de colmos, sinalizando que essa altura de manejo pode ter sido excessiva. A redução dessa altura poderia melhorar a estrutura do dossel com impactos sobre o consumo e o desempenho animal. A adoção de lotação contínua no capim-pojuca pode criar uma estrutura de pastejo em mosaico no pasto, com áreas muito pastejadas e outras pouco pastejadas, exigindo atenção constante com a pressão de pastejo, o que pode dificultar o seu manejo em condições comerciais. A adoção do pastejo rotativo pode facilitar seu manejo e, da mesma forma que no capimtangola, impactar a capacidade de suporte, o consumo e o desempenho animal.

\section{Conclusões}

O capim-tangola apresenta melhor valor nutritivo e proporciona maior produção individual de leite por vaca em relação ao capim-pojuca, com o capim-humidícola em posição intermediária. A produção de leite por área é semelhante entre as espécies, indicando que qualquer delas pode ser utilizada na formação de pastagens em áreas de várzea sob pastejo contínuo por vacas em lactação.

\section{Agradecimentos}

À Fundação de Amparo à Pesquisa do Estado de Minas Gerais (FAPEMIG), pelo apoio financeiro para custeio dos projetos e pela concessão da bolsa de produtividade em pesquisa.

\section{Referências}

ANDRADE, F.M.E. Produção de forragem e valor alimentício do capim-marandu submetido a regimes de lotação contínua por bovinos de corte. 2003. 125f. Dissertação (Mestrado em Agronomia - Ciência Animal e Pastagem) - Escola Superior de Agricultura Luiz de Queiroz/Universidade de São Paulo, Piracicaba.

ANDRADE, C.M.S.; ASSIS, G.M.L.; FAZOLIN, M. et al. Capimtangola: gramínea forrageira recomendada para solos de baixa permeabilidade do Acre. Rio Branco: Embrapa Acre, 2009. $63 p$.
ANTUNES, F.Z. Caracterização climática do Estado de Minas Gerais. Informe Agropecuário, v.12, n.138, p.9-13, 1986.

ALVIM, M.J.; SIMÃO NETO, M.; DUSI, G.A. Efeito da disponibilidade de forragem e da adubação em pastagem de capimangola sobre a produção de leite. Pesquisa Agropecuária Brasileira, v.27, n.11, p.1541-1550, 1992.

CARNEVALLI, R.A.; DA SILVA, S.C.; FAGUNDES, J.L. et al. Desempenho de ovinos e respostas de pastagens de Tifton 85 (Cynodon spp.) sob lotação contínua. Scientia Agrícola, v.58, n.1, p.7-15, 2001.

CATALDO, D.A.; HAROON, M.; SCHARDEN, M.L. Rapid colorimetric determination of nitrate in plant tissue by nitrification of salicylic acid. Community Soil Science Plant Anal, v.6, p.71-81, 1975.

CUNHA M.A.D.; LEITE, G.G.; DIOGO, J.M.S. et al. Características morfológicas do Paspalum atratum cv. Pojuca submetido ao pastejo rotacionado. Dinamica de perfilhamento e elongação de folha. Revista Brasileira de Zootecnia, v.30, n.3, p.935-940, 2001.

DIFANTE, G.S.; MARCHEZAN, E.; VILLA, S.C.C. et al. Produção de novilhos de corte com suplementação em pastagem de azevém submetida a doses de nitrogênio. Revista Brasileira de Zootecnia, v.35, n.3, p.1107-1113, 2006 (supl.).

DIFANTE, G.S.; MARCHEZAN, E.; ROCHA, M.G. et al. Produção de forragem e rentabilidade da recria de novilhos de corte em área de várzea. Revista Brasileira de Zootecnia, v.34, n.2, p.433-441, 2005.

EUCLIDES, V.P.B.; MACEDO, M.C.M.; VALLE, C.B. et al Produção de forragem em características da estrutura do dossel de cultivares Brachiaria brizantha sob pastejo. Pesquisa Agropecuária Brasileira, v.43, n.12, p.1805-1812, 2008.

FAGERIA, N.K.; SANTOS, A.B.; CUTRIM, V.A. Produtividade de arroz irrigado e eficiência de uso do nitrogênio influenciadas pela fertilização nitrogenada. Pesquisa Agropecuária Brasileira v.42, n.7, p.1029-1034, 2007.

FAGUNDES, J.L.; FONSECA, D.M.; GOMIDE, J.A. et al. Acúmulo de forragem em pastos de Brachiaria decumbens adubados com nitrogênio. Pesquisa Agropecuária Brasileira, v.40, n.4, p.397-403, 2005.

KALMBACHER, R.S.; MARTIN, F.G.; KRETSCHMER JUNIOR, A.E. Performace os cattle grazing pastures based on Paspalum atratum cv. Suerte. Tropical Grasslands, v.31, p.58-66, 1997.

MARCHEZAN, E.; VIZZOTTO, V.R.; ROCHA, M.G. et al. Produção animal em várzea sistematizada cultivada com forrageiras de estação fria submetidas a diferentes níveis de adubação. Ciência Rural, v.32, n.2, p.303-308, 2002.

NASCIMENTO JÚNIOR, D.; SANTOS, M.E.R.; SILVEIRA, M.C.T et al. Atualidade sobre manejo do pastejo nos trópicos. In: SIMPÓSIO SOBRE MANEJO ESTRATÉGICO DA PASTAGEM, 5., 2010, Viçosa, MG. Anais... Viçosa, MG: UFV; DZO, 2010. p. $1-40$.

PINTO, L.F.M. Dinâmica do acúmulo de matéria seca em pastagens de Cynodon spp. 2000. 124f. Dissertação (Mestrado em Agronomia - Ciência Animal e Pastagem) - Escola Superior de Agricultura Luiz de Queiroz/Universidade de São Paulo, Piracicaba

PINTO, L.F.M.; DA SILVA, S.C.; SBRISSIA, A.F. et al. Dinâmica do acúmulo de matéria seca em pastagens de Tifton 85 sob pastejo. Scientia Agricola, v.58, n.3, p.439-447, 2001.

POPPI, D.P.; HUGHES, T.P.; L'HUILLIER, P.J. Intake of pasture by grazing ruminants. In: NICOL, A.M. (Ed.). Livestock feeding on pasture. Hamilton: New Zealand Society of Animal Production, 1987. p.55-64. (Occasional publication, 10).

ROSITO, J.M.; MARCHEZAN, E.; QUADROS, F.L.F. Seleção de dieta por bovinos em pastagem cultivada em área de várzea. Ciência Rural, v.34, n.4, p.1191-1196, 2004.

RUGGIERI, A.C.; JANUSCKIEWICS, E.R.; CASAGRANDE, D.R. et al. Morphological composition of marandu palisade grass pasture 
managed under different herbage alloawance grazed by dairy cattle in rotational stocking system. In: JOINT ANNUAL ANIMAL SCIENCE MEETING, 2008, Indianapolis. Joint ADSA-ASAS Annual Meeting, 2008, Proceedings... Champaing: American Society of Animal Science, 2008. v.86, p.372.

SARMENTO, D.O.L. Comportamento ingestivo de bovinos em pastos de capim-marandu submetidos a regime de lotação continua. 2003. 76f. Dissertação (Mestrado em Agronomia Ciência Animal e Pastagem) - Escola Superior de Agricultura Luiz de Queiroz/Universidade de São Paulo, Piracicaba.

SBRISSIA, A.F. Morfogênese, dinâmica do perfilhamento e do acúmulo de forragem em pastos de capim-Marandu sob lotação contínua. 2004. 171f. Tese (Doutorado em Agronomia - Ciência Animal e Pastagens) - Escola Superior de Agricultura Luiz de Queiroz/Universidade de São Paulo, Piracicaba.

SBRISSIA, A.F.; DA SILVA, S.C. Compensação tamanho/densidade populacional de perfilhos em pastos de capim-marandu. Revista Brasileira de Zootecnia, v.37, n.1, p.35-47, 2008.
SILVA, D.M.S; DIAS-FILHO, M.B. Banco de sementes de plantas daninhas em solo cultivado com pastagens de Brachiaria brizantha e Brachiaria humidicola de diferentes idades. Planta Daninha, v.19, n.2, p.179-185, 2001.

SILVA, D.J.; QUEIROZ, C. Análise de alimentos (Métodos químicos e biológicos). Viçosa, MG: Universidade Federal de Viçosa, 2002. 235p.

TOKARNIA, C.H.; DÖBEREINER, J.; PEIXOTO, P.V. Poisonous plants affecting livestock in Brazil. Toxicon, v.40, n.2, p.1635-1660, 2002.

TUFFI SANTOS, L.D.; SANTOS, I.C.; OLIVEIRA, C.H. et al. Levantamento fitossociológico em pastagens degradadas sob condições de várzea. Planta Daninha, v.22, n.3, p.343-349, 2004.

UNDERSANDER, D.; COMBS, D.; HOWARD, T. et al. Nitrate poisoning in cattle, sheep and goats. Madison: University of Wisconsin, 2001. Disponível em: <http://uwex.edu/ces/forage/ pubs/nitrate.htm>. Acesso em: 18 dez. 2010. 